\title{
リモートセンシングを用いた嘉瀬川ダム流域の 被覆状況調査と流出土砂量の推定
}

THE INVESTIGATION INTO THE LAND CONDITION OF KASEGAWA DAM RESERVOIR BASIN BY USING THE REMOTE-SENSING DATA AND THE ESTIMATE OF ITS SEDIMENT YIELD VOLUME

\author{
橋本晴行 ${ }^{1} \cdot$ 渡辺勝利 ${ }^{2} \cdot$ 全 炳德 $^{3} \cdot$ 上野賢仁 ${ }^{4} \cdot$ 山中 稔 $^{5} \cdot$ \\ 笠井美青 ${ }^{6} \cdot$ 野上昭治 $^{7} \cdot$ 緒方 $^{\text {勤 }}{ }^{8}$ \\ Haruyuki HASHIMOTO, Katsutoshi WATANABE, Byungdug JUN,Kenji UENO, \\ Minoru YAMANAKA, Mio KASAI, Shouji NOGAMI and Tsutomu OGATA \\ ${ }^{1}$ 正会員 工博 九州大学助教授 大学院工学研究院 (T812-8581 福岡市東区箱崎 6-10-1) \\ ${ }^{2}$ 正会員 工博 徳山工業高等専門学校助手 土木建築工学科（₹745-8585 山口県徳山市久米高城 3538） \\ ${ }^{3}$ 正会員工博 (株)ペック (T850-0004 長崎市下西山町 7-1) \\ ${ }^{4}$ 正会員 工博 崇城大学 (旧名熊本工業大学) 講師 工学部環境建設工学科 (テ860-0082 熊本県熊本市池田 4-22-1) \\ ${ }^{5}$ 正会員 修 (工) 長崎大学講師 工学部社会開発工学科（テ852-8521 長崎市文教町 1-14) \\ ${ }^{6}$ 農修 九州大学助手 農学部附属演習林（†883-04 宮崎県東且杵郡椎葉村大字大河内 949） \\ 7 元建設省嘉瀬川タム工事事務所所長（テ849-0922 佐賀市高木瀬東 2-16-35） \\ 8 建設省嘉瀨川ダム工事事務所調查設計課長（テ849-0922 佐賀市高木瀬東 2-16-35）
}

\begin{abstract}
It is important to estimate sediment yield volume accurately in reservoir basins in the planning of the dam-construction. In the present study we select Kasegawa dam under construction in Saga Prefecture as a case study area. We first investigate the land surface condition and vegetation activity in the reservoir basin by using rcmotc-sensing data. Secondly we examine sediment grain size distribution in the rivers in the reservoir basin. On the basis of these results and sediment transport mechanics we finally estimate the sediment yield volume from the reservoir basin.
\end{abstract}

Key Words : remote sensing, Kasegawa dam reservoir, sediment yield, reservoir sedimentation

1.はじめに

ダム貯水池の計画に際しては, 通常, 類似地域の 既設ダムの比堆砂量より計画堆砂量が見積もられ, それを基に堆砂対策が練られている。佐賀県佐賀郡 富士町において，現在，ダム建設事業着手の段階に 入っている嘉瀬川ダムについても同様な方法により 計画堆砂量が評価されている。しかしながら, 比堆 砂量が安定化するためには, 経過年数が少なくとも 15 年〜 20 年を要するが，類似地域に 15 年 20 年以 上経過した既設ダムが存在するとは限らない。

LANDSAT 衛星データは $30 \mathrm{~m} \times 30 \mathrm{~m}$ の分解能であ
るが, 河川流域スケールのような広範囲を一望でき る上, 今後分解能の向上も期待される. 従って, 衛 星データを併用して正確な流域情報を活用すれば， 流出土砂量の精度のより良い評価につなげることが できるものと期待される。

本研究の目的は,リモートセンシングを併用し， 既設ダムの比堆砂量を用いることなしに，ダム堆砂 量を評価することである。

嘉瀬川ダムは, 洪水調節, 流水の正常な機能の維 持, 潅溉用水及び都市用水の補給を目的として計画 された多目的ダムである。本研究は, 嘉瀬川ダムを 取り上げ，リモートセンシングを用いた流域の被覆 
状況調査を行うとともに, その結果と現地調査, 土 砂水理学的な取り扱いをもとに嘉瀬川ダムの堆砂量 を推定したものである。まず，リモートセンシング や現地調査などにより流域の植物活性度や被覆状況 を明らかにする，次に，現地調査により嘉瀬川ダム 流域内の各河川の河道内堆積土砂の粒度特性を調べ る. その結果や周辺の既設ダムの堆砂データ, 土砂 水理学の知見などをもとに嘉瀬川ダムへの流入土砂 量を推定する。

\section{2. 嘉瀬川ダム流域の地盤条件と被覆状況}

\section{（1）嘉瀬川ダム流域の地盤条件}

嘉瀬川ダム流域の表層地質図及び風化状況図を地 理情報システム（GIS）にデジタイザーによりデー タ入力し嘉瀬川ダム流域の土砂生産について調べた。

図- 1 に嘉瀬川ダム流域の表層地質図を示す。嘉 瀬川ダム流域はほほ花崗岩類で構成されている，花 崗岩類は一般に風化されやすく, 風化が進行すると 砂礫サイズの「まさ土」となる。このような「まさ 土」からなる地域での土砂流出は，比較的小規模な 降雨であっても流出する傾向にある.したがって， 嘉瀬川流域からの土砂の流出量は, 他の表層岩類か らなる地域よりも多いことが予想される。

図- 2 は，流域队の風化状況（風化殼の深度）を 示す ${ }^{1)}$. 風化状況が $10 \mathrm{~m}$ 以深の割合を算出した結果, 北山ダム流域 : $71.5 \%$, 嘉瀬川ダム流域 : $96.5 \%$ （北山ダム流域を除く），嘉瀬川ダム流域： $86.5 \%$ （北山ダム流域を含む）であることが分かった。し たがって, 嘉瀬川ダム流域（北山ダム流域を除く） の方が北山ダム流域よりも，土砂の生産性は高いこ とが予測される。

なお，この流域での大規模な崩壊・地すべりの発 生は，記録には残っていない。

\section{（2）嘉瀬川ダム流域の植生状況}

樹木などの活性度は，環境の変化に大きく影響を 受ける．植物活性度が低下すると地盤に悪影響（例 えば，結合力の低下による地盤の脆弱化）を及ほし， その結果, 土砂流出量の増大に繋がると考えられる. そこで，嘉瀬川ダム及び北山ダム周辺の植生につい て人工衛星データ（LANDSAT-5/TM）解析を行っ た。

\section{1 ）植生指標 NDVI}

植物の状態を分光特性として表現する場合, 植物 の葉に含まれるクロロフィルの量, 葉の量, 樹木の 種類などにより, 他の物体に比べて極めて特徴のあ

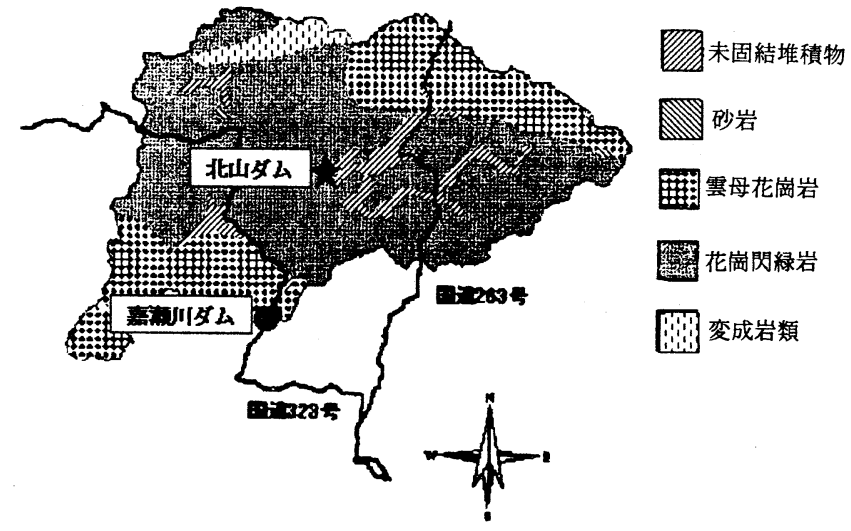

$10 \mathrm{~km}$

図-1＼cjkstart嘉瀬川ダム流域の表層地質図

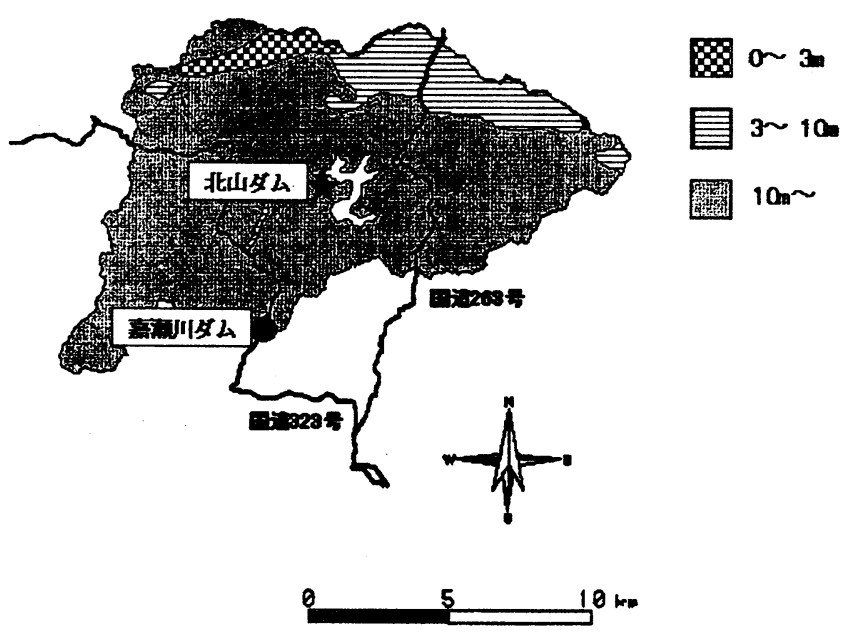

図-2 嘉瀬川ダム流域の風化状況図

る分光反射特性を持っている．これらのことから， 植物の分光反射特性が分かれば，植物の生育状態を 判断することが可能である. この分光反射特性を利 用して，人工衛星データ及び現地調査により植物活 性の大きさが調査できる。植物活性の大きさを表す 指標として, 植生指標 NDVI が NDVI $=\{(\mathrm{NIR}$ $-\mathrm{RED}) /(\mathrm{NIR}+\mathrm{RED})+1\} \times 128$ として定義されて いる ${ }^{2)}$.ここに, NIR : 近赤外域バンドの反射率, RED：赤色光域バンドの反射率である.

\section{2）人工衛星データによる植生調査}

1994 年から 1997 年の LANDSAT データから嘉瀬 川ダム流域の植生指標 NDVIを調べた。その結果, 以下のことが判明した。

(1) 1994 年 3 月 31 日のデータが最も高い植物活性度 を示す。

(2) 1996 年と 1997 年のデータにはあまり差が見られ ない（これは，1991 年の 19 号台風により影響を受 けていた樹木が 1994 年には回復しているが, 1994 


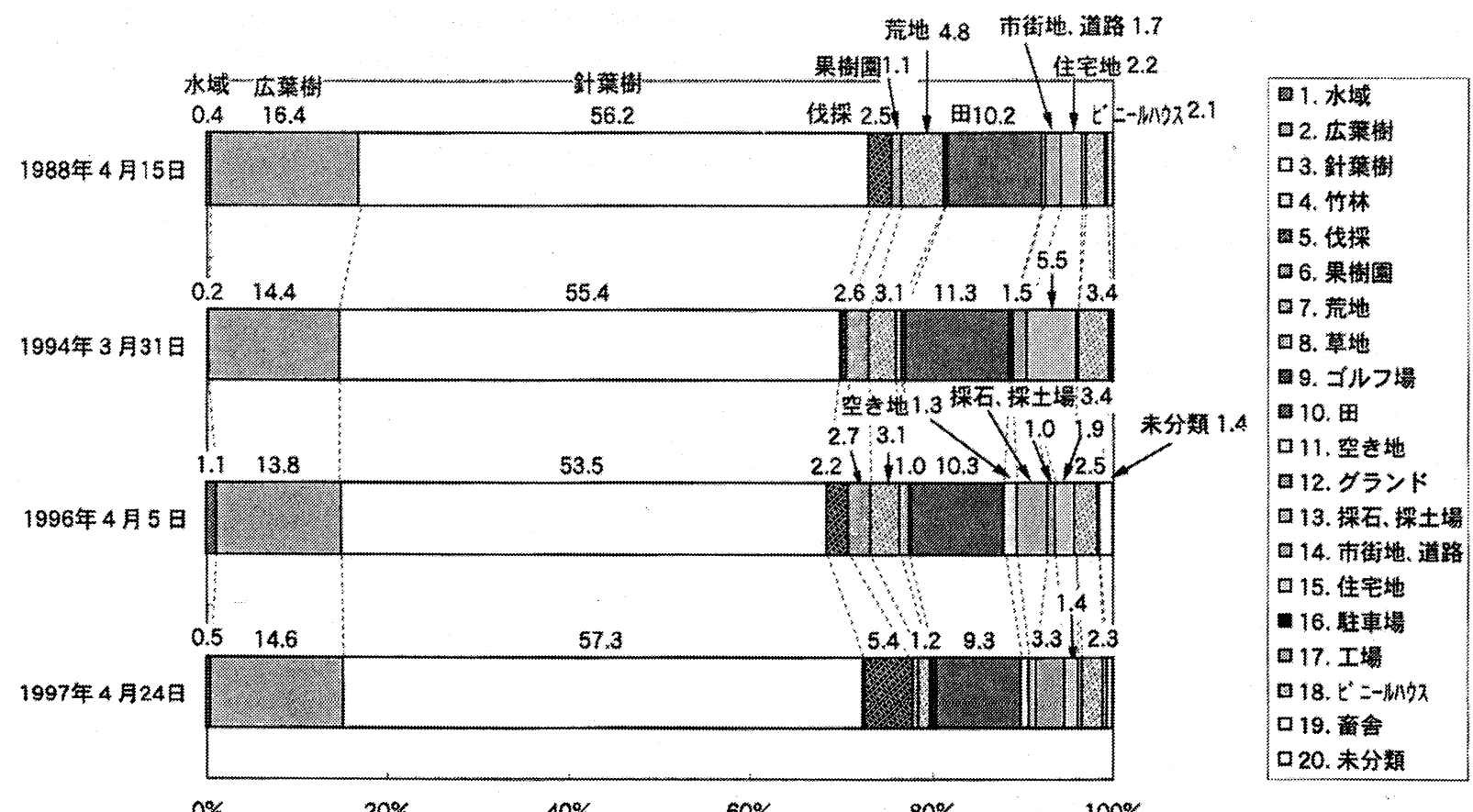

図-3 嘉瀬川ダム流域（北山ダム流域を除く）の被覆状況変化

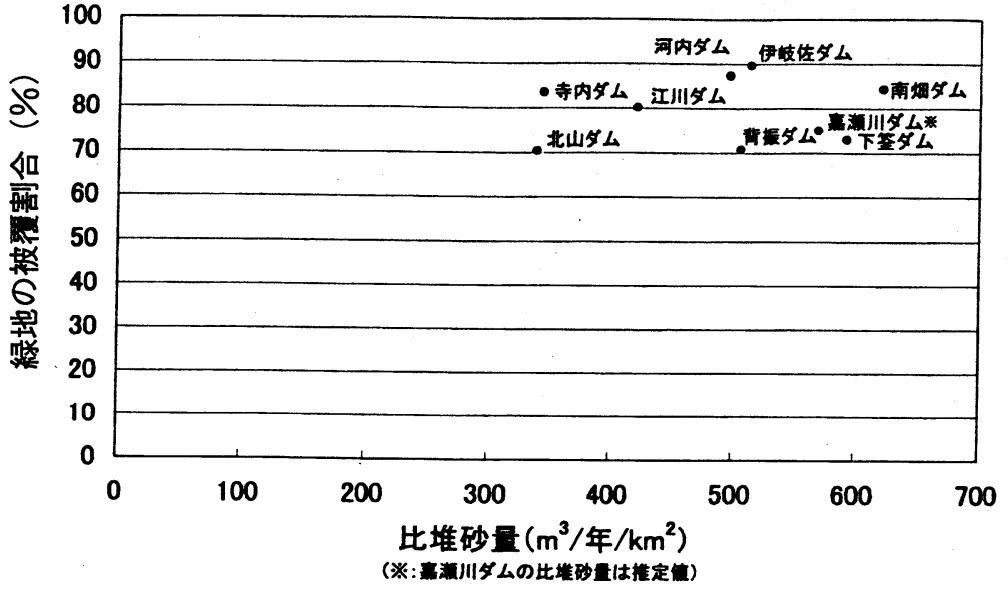

図-4 各ダム流域の緑地の被覆割合と比堆砂量との関係
寺内の各ダム）を解析し，各ダム流 域の被覆状況と比堆砂量との関係を 調べる。また，植生指標（NDVI）を 求め, 比堆砂量との関係についても 調べる。

\section{1 ）嘉瀬川ダム流域の被覆状況}

1997 年 4 月 24 日のデータから作成 した被覆分類図に,ダム流域を重ね 合わせて，被覆状況の割合をみた。 嘉瀬川ダム流域（北山ダム流域を除 く）は，針葉樹 $57 \%$, 広葉樹 $15 \%$, 田 $9 \%$, 伐採した部分 $5 \%$ である。 北山夕゙ム流域は，針葉樹 $49 \%$, 広葉樹 $16 \%$, 田 $9 \%$, 伐採地 $7 \%$ である。嘉 年の夏から始まった渇水の影響が植物の活性度を 低下させたものと思われる）.

(3)植物活性度が高い地域（北山ダム流域）とそうで ない地域（北山ダム流域を除いた地域）に分けられ る.

\section{（3）嘉瀬川ダム流域および周辺既設ダム流域の被} 覆状況

まず，1997 年の LANDSAT 衛星デー夕を用いて 嘉瀬川ダム流域の被覆分類図を作成し被覆割合を求 める．次に，1988，1994，1996年のデータを解析 し，被覆の経年変化を調べる．最後に，1997年の データを用いて, 筑紫山系と筑後川流域のダム（南 畑, 背振, 伊岐佐, 河内, 北山, 松原, 下鉒, 江川, 瀬川ダム流域は，北山ダム流域と比較して針葉樹の 割合が若干大きな值になっている。

\section{2 ）嘉瀬川ダム流域の被覆状況の経年変化}

1997 年のデータに加えて $, 1988,1994 ， 1996$ 年 のデータを解析し，被覆状況の変化を見た（図-3）. 4 年分の被覆分類図を比較すると，流域内で大きな 変化は見られなかった。 また，樹林地と平地との境 界はほとんど変化がなく, 流域内で大きな土地利用 の変化は無いものと思われる.

また，1975年と 1993 年に撮影された航空写真か ら流域の被覆状況を見ると, 1975 年当時は伐採され ている領域が多く, 1993 年では非常に少ないことが わかる。 


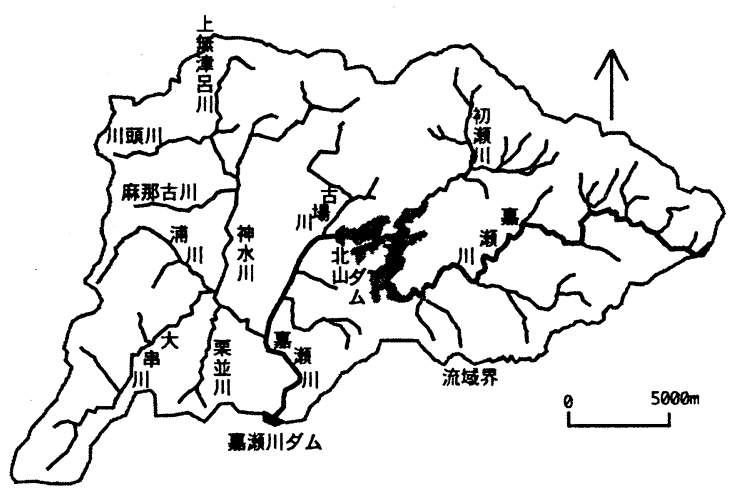

流域の被覆割合は，限られた範囲内ではあるが，緑 地（樹木）の被覆割合と比堆砂量とは明確な関係は 見られない。

\section{5 ）植物活性度と比堆砂量の関係}

各ダム流域の植物活性度すなわち植生指標 （NDVI）と比堆砂量との関係については, 本調査 の範囲内では明確な相関は見られなかった。

3. 嘉瀬川ダムおよび北山ダムに流入する河川 の特性
図-5 嘉瀬川ダム，北山ダムに流入する河川

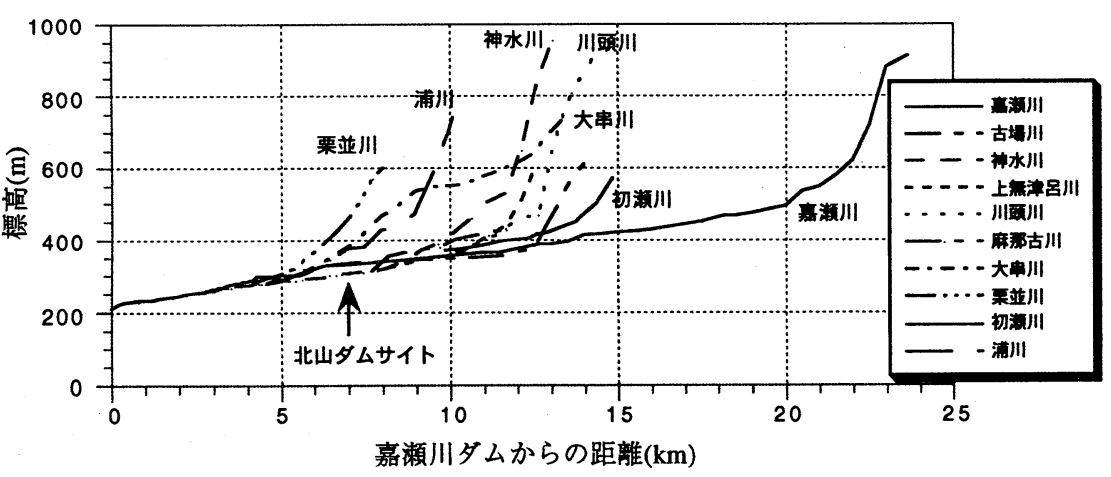

図-6＼cjkstart各河川の綖断図

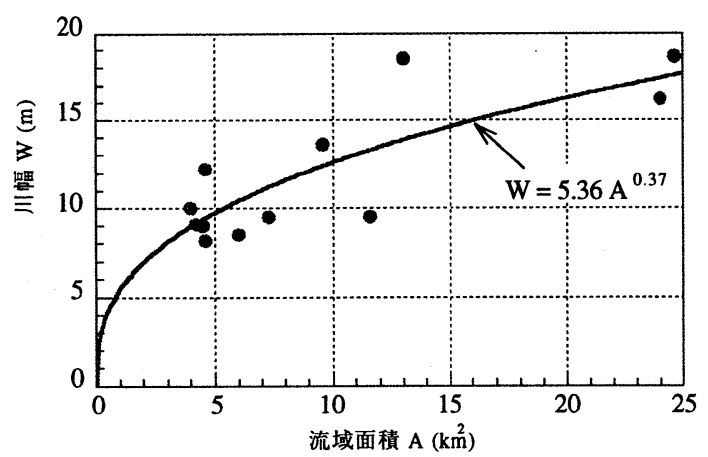

図-7 流域面積と河幅の関係

\section{3）各ダム流域の被覆分類図}

各ダム流域の被覆分類図を作成し，これをもとに 被覆割合を比較した。北山ダム流域と嘉瀬川ダム流 域（北山ダム流域を除く）の被覆割合はほほ同じ割 合で, 他のダムと比較して, 田畑, 草地等の割合が 高い. 南畑ダム, 背振ダム, 河内ダムは近接してい るが, 被覆割合は若干違っている. 江川ダムと寺内 ダムは似通った割合であった。

\section{4 ）各ダム流域の緑地（樹木）の被覆状況と比堆砂 量の関係}

図-4は各ダム流域の緑地（樹木）の被覆割合と比 堆砂量との関係を示したものである. 調査対象ダム
嘉瀬川ダム貯水池に直接流入 する主な河川は神水川, 浦川, 大串川，栗並川，嘉瀬川であ る（図-5）。嘉瀬川には嘉瀬川 ダムサイトから約 $7 \mathrm{~km}$ 上流に 北山ダム（流域面積 $54.63 \mathrm{~km}^{2}$, 1957 年竣工）がある。この北 山ダムには嘉瀬川と初瀬川が流 入している.

本章では,これらの河川につ いて流域面積, 縦断勾配, 河幅, 土砂の粒度特性を調べた。

\section{（1）各河川の縦断勾配}

図-6に各河川の縦断図を示す，北山ダムに流入す る嘉瀬川, 初瀬川は嘉瀬川ダムに流入する他の河川 よりも緩勾配である。

\section{（2）河幅}

各河川が他川と合流する直前の地点および神水川 における流域面積 $24.6 \mathrm{~km}^{2}$ の地点において調べた河 幅と流域面積の調査結果を図-7に示す。同図には回 帰式 $\mathrm{W}=5.36 \mathrm{~A}^{0.37}$ も示す.ここに, 河幅 $\mathrm{W}$ の単 位は $\mathrm{m}$ ，流域面積 $\mathrm{A}$ のそれは $\mathrm{km}^{2}$ である。

\section{（3）河道土砂の粒度特性}

土砂の粒度特性については，まず，各流域の出口 に近い場所において $1 \mathrm{~m} \times 1 \mathrm{~m}$ のプロットを設け，プ ロットに含まれるレキについて大きい方から 40 個 抽出し、レキ径を計測した.レキ径は，3次元の方 向に計測されたレキの長さの平均値とした。. 次に, $100 \mathrm{~mm}$ 以下の土砂レキについては, JIS 規格のふる いを用いて粒度分析を行った。

図-8は，1m×1mのプロットにおいて測定された レキ径分布を示す。それぞれの河川から生産される レキ径分布は大まかにいえばほ等しい。100mm 


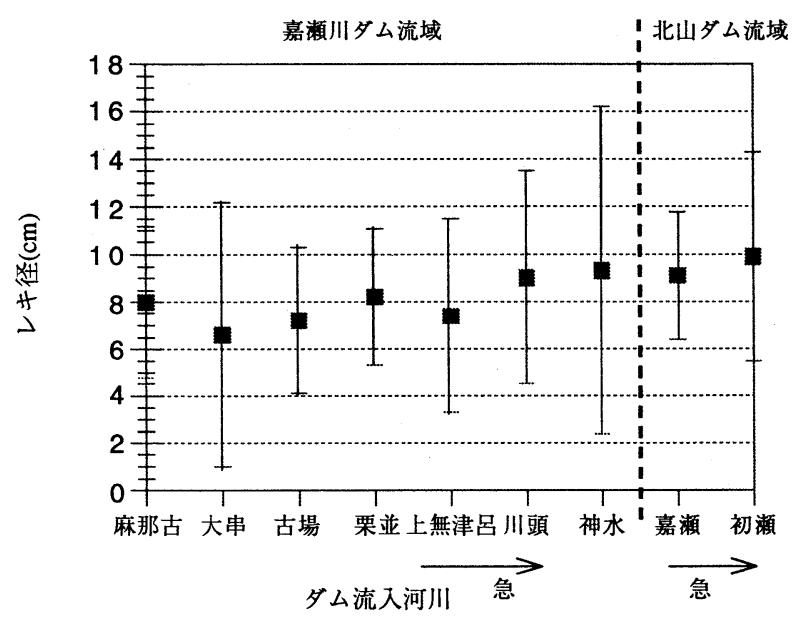

図-8＼cjkstart各河川における設定プロット内の最大レキの レキ径分布（平均河床勾配順）

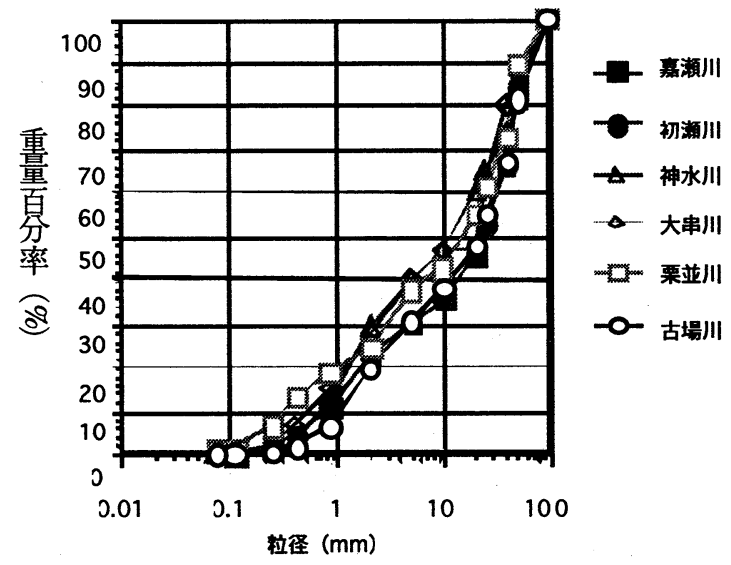

図-9＼cjkstart各河川における堆積土砂の粒径加積曲線

以下の粒径の土砂について粒度分析した結果を図 -9 に示す. 粒度分析からも, 河道土砂の粒度特性は 河川間に大きな差異は認められないことが分かる。

\section{4. 嘉瀬川ダム周辺および筑後川流域における 既設ダムの堆砂状況}

河川流量が既知の場合にダム堆砂量を評価する方 法について検討する。 まず，既設ダムの堆砂状況の 事例として, 嘉瀬川ダム周辺から, 筑紫山系にある 南畑ダム, 背振ダム, 河内ダム, 北山ダム, 伊岐佐 ダムを選ぶ.これらの地域はいづれも花崗岩質の地 質からなる地域である。次に, これらの地域とは地 質条件の異なる地域として筑後川流域から松原ダム， 下鉒ダム, 江川ダム, 寺内ダムを選ぶ. 以上の既設 ダムについて堆砂状況を調べ, 土砂水理学の知見を 基にダム堆砂量と河川流量との関係式を求める.

（1）比堆砂量から見た既設ダムの堆砂状況

貯水容量 200 万 $\mathrm{m}^{3}$ 以上, 堆砂率 $25 \%$ 以下, 経過

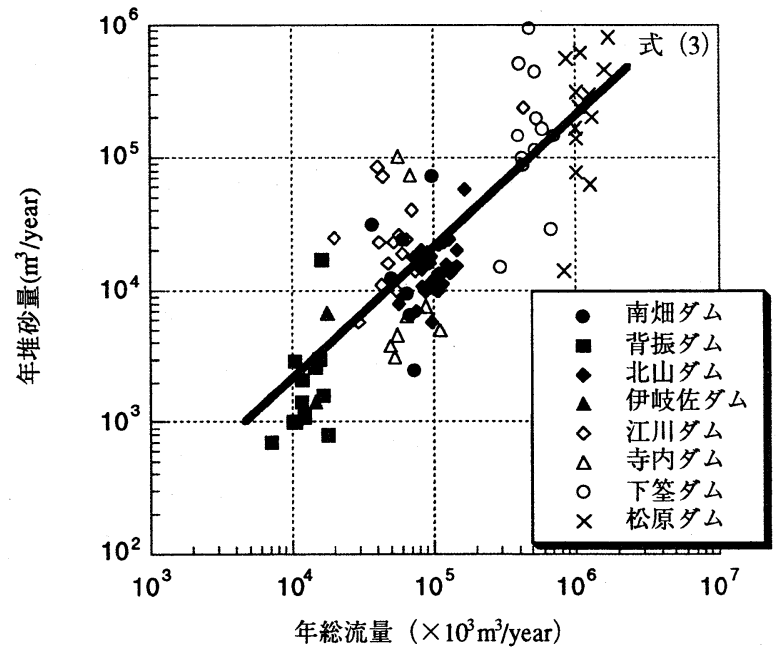

図-10 年堆砂量と年総流入量との関係

（経過年数10年以上のデータを使用）

年数 10 年以上の貯水池について比堆砂量と流域面 積との関係を水系別に示された図 ${ }^{3)} に$ ，本調査結果 をプロットした，紙面の都合上，図は省略している が, 筑紫山系のダム堆砂状況は, わが国で最も流出 土砂量の少ない中国地方の河川の近傍にプロットさ れ，中国地方の堆砂状況に類似していることが分かっ た. 一方, 筑後川流域のダムについては, 江川・寺 内ダムは筑紫山系のダム堆砂状況と同じであるが, 松原・下鉒ダムは, 木曾川, 吉野川など構造線沿い の河川に近い堆砂状況であることが分かった。

\section{（2）年堆砂量と年総流量との関係}

計画堆砂量算定においては, 通常, 類似な流域特 性の既設ダムを選び，その比堆砂量から算定される ことが行われる．比堆砂量が安定化するためには， 経過年数としては少なくとも 15 年〜20 年を要する が, 類似地域に 15 年〜20 年以上経過した既設ダム が常に存在するとは限らない。ここでは, 比堆砂量 以外の方法で堆砂量を算定する方法を考えてみよう。 まず，掃流砂や浮流砂を伴う場合の流砂量について 考える．断面全体の流量を $Q$, 流砂量を $Q_{s}$ とそれぞ れおくと，流砂量式は簡単に

$$
Q_{s}=Q \frac{K}{s \varphi} I_{e}
$$

となる ${ }^{4)}$ 。ここに， $I_{e}$ :エネルギー勾配 河床勾 配, $\varphi$ : 流速係数, $s$ : 粒子水中比重である，Kを簡 単に定数として取り扱い，式（1）を積分すると

$\int_{0}^{1 y e a r} Q_{s} d t=\int_{0}^{1 \text { year }} Q \frac{K}{s \varphi} L_{e} d t \approx \frac{K}{s \varphi} L_{e} \int_{0}^{1 y e a r} Q d t$

取り扱いとしてはかなり粗いものではあるが，年流 砂量（う年堆砂量）が年総流量に比例することが分 


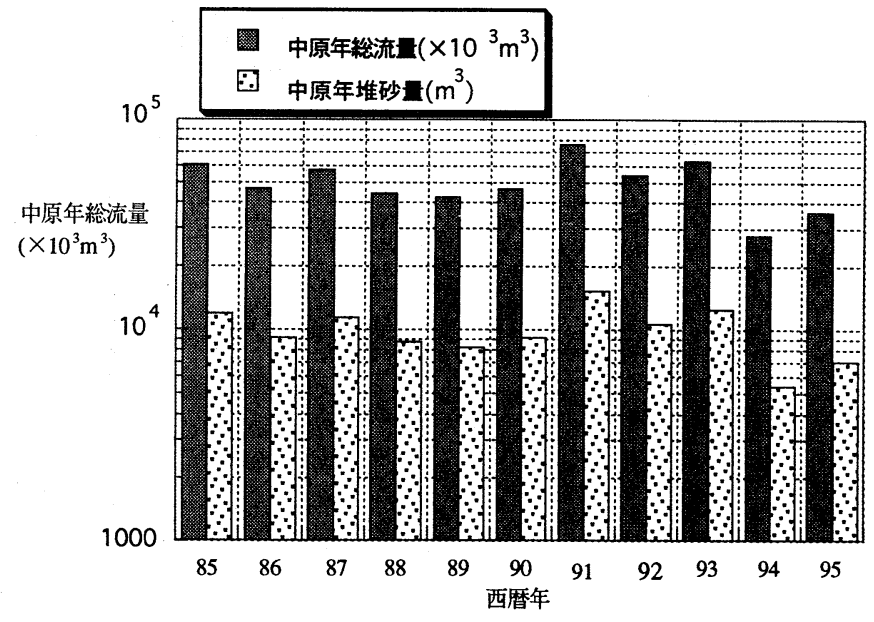

図-11 嘉瀬川中原地点における実測年総流量と 推定年堆砂量の变化

かる. 図-10は，筑紫山系および筑後川流域のダ ムにおける年堆砂量と年総流入量との関係を示した ものである．明らかに，年堆砂量は年総流入量に関 連づけられ，回帰式として次式を得る。

$$
\int_{0}^{1 \text { year }} Q_{s} d t=1.378 \times 10^{-4} \times\left(\int_{0}^{1 \text { year }} Q d t\right)^{1.02}
$$

(単位: $\mathrm{m}^{3} /$ year)

これは式 (2)にほほ一致している。このことは, 調 査対象ダムの流域が大規模な崩壊・地すべりによる 土砂生産の場ではなく，また土砂流出も洪水による 河道からの掃流・浮流による流出が主であることを 物語っている。これは2，3章で見た嘉瀬川ダム流 域の特性にも適合するものであり, 式 (3) の嘉瀬 川ダムへの適用には問題はないものと考えられる.

以上のことから, 貯水池計画の当該河川流量の数 值データが分かれば年流砂量が明らかになり，その 結果, 計画対象ダムにおける計画堆砂量が評価でき ることになる。

\section{5. 嘉瀬川ダムの堆砂量の推定}

年堆砂量の推定式（3）を用いて嘉瀬川中原地点 の実測流量を基に年堆砂量を推定してみよう。

図-11にその結果を示す. 中原地点では平均的に は年間 $50.51 \times 10^{6} \mathrm{~m}^{3}$ の流量があり, その結果として 平均 $9,932 \mathrm{~m}^{3}$ の年間流砂量が推定されることになる.

当然, 推定式には誤差が含まれており, 中原地点で の流量規模においては約 $2,000 \sim 100,000 \mathrm{~m}^{3}$ の年間流 砂量の推定幅が考えられる。

従って, 中原地点の流域面積が $24.6 \mathrm{~km}^{2}$, 嘉瀬川 ダム地点での流域面積が $73.8 \mathrm{~km}^{2}$ （北山ダム流域を
除外）であることを考慮して，嘉瀬川ダム地点の流 砂量を推定すると, 1 年間で平均 $29,800 \mathrm{~m}^{3}, 100$ 年 間では平均 298 万 $\mathrm{m}^{3}$ となる. 計画堆砂量は 430 万 $\mathrm{m}^{3}$ とされているが, 推定式の精度を考えると両者 は良く一致していると言える。

\section{6.おわりに}

以上，リモートセンシング情報を用いて，嘉瀬川 ダム流域と周辺既設ダム流域の被覆割合や植生指標 を求め, 比較するとともに, 比堆砂量との関係を調 ベた。また嘉瀬川ダム流域の河道土砂の粒度特性を 調べるとともに，筑紫山系および筑後川流域の既設 ダムについて堆砂状況を調べた. 得られた結果を要 約すると以下のようである。

（1）嘉瀬川ダム, 北山ダム流域の地質は風化され やすい花崗岩類から成る．また，嘉瀬川ダム流域の 方が北山ダム流域より風化が進んでいる。

（2）嘉瀬川ダム流域の方が，北山ダム流域より植 物活性度が低い。

（3）北山夕゙ム流域は，針葉樹 $49 \%$, 広葉樹 $16 \%$, 田 $9 \%$, 伐採地 $7 \%$ である. 嘉瀬川ダム流域は，北 山ダム流域と比較して，針葉樹が $57 \%$ と若干大きな 值になっているが，概ね同様な被覆状況である.

（4）衛星デー夕解析の結果, 流域内の被覆状況は 大きな経年変化は見られなかった。 また，大きな土 地利用の変化もなかった.

（5）年間のダム堆砂量と年間の総流量との関係式 を求め, これを用いて嘉瀬川ダムの 100 年間の堆砂 量を 298 万 $\mathrm{m}^{3}$ と評価した。

謝辞：本研究は水理委員 会河川懇談会における土木 学会・建設省共同研究（平成 9 11 年度）「ダム流 入土砂の分級過程とそれに対応した効率的除去手法 の研究」の一環として行ったものである。また，大 成建設 (株) 技術研究所の石野和男氏には研究計画 の段階において助言をいただいた。ここに記して謝 意を表します。

\section{参考文献}

1) 経済企画庁総合開発局, $1: 100,000$ 土地分類図（佐 賀県），（財）日本地図センター, 1992.

2) 日本リモートセンシング研究会編 : 図解リモートセ ンシング, 1992.

3 ) 芦田和男, 高橋保, 道上正規：河川の土砂災害と対 策, 森北出版（株），1983.

4）椿東一郎：水理学 II，森北出版（株），1974.

(2000. 10. 2受付) 